\title{
FROM ECONOMIC PROTECTORATE TO THE TRANSATLANTIC TRADE AND INVESTMENT PARTNERSHIP: A NEW-AGE RELATIONSHIP BETWEEN THE EUROPEAN UNION AND THE UNITED STATES?
}

\section{Elif UÇKAN DAĞDEMİR*}

\begin{abstract}
The European Union (EU) and the United States (US) are the largest economies and the biggest trade and investment partners of the world economy. The relations between the EU and the US are vigorous and are rooted in centuries of shared economic and political heritage. In this article, trade relations between the EU and the US after the Second World War are examined. Besides the trade data between the parties, the investment data are also evaluated to provide insight into the magnitude of the transatlantic marketplace. The aim of the paper is to inquire whether the newly-initiated Transatlantic Trade and Investment Partnership pledges new dimensions and expansions to the existing relations or just a new sight to the status quo. The paper offers an appraisal and evaluation of the trade relations, taking into consideration the main trade disputes, and it intends to provide a precise assessment of the Transatlantic Trade and Investment Partnership.
\end{abstract}

Keywords: European Union, United States, EU-US Relations, Transatlantic Trade and Investment Partnership

\section{EKONOMIK HAMILIKTEN TRANSATLANTIK TICARET VE YATIRIM ORTAKLIĞINA: AVRUPA BİRLIĞİ VE AMERİKA BİRLEŞIKK DEVLETLERİ ARASINDA YENİ-NESIL BİR İLISŞKİ Mİ? \\ $\ddot{O} z$}

Avrupa Birliği ve Amerika Birleşik Devletleri dünya ekonomisinin en büyük ticaret ve yatırım ortaklarldır. Avrupa Birliği ve Amerika Birleşik Devletleri arasındaki ilişkiler yüzyıllardır paylaşılan ekonomik ve siyasi bir miras üzerine inşa edilmiş olan güçlü bir ilişkidir. Bu çalışmada, İkinci Dünya Savaşı sonrasında Avrupa Birliği ve Amerika Birleşik Devletleri arasındaki ticari ilişkiler

\footnotetext{
* Assoc. Prof. (PhD), Anadolu University, Faculty of Economics and Administrative Sciences, Department of Economics, e-mail: euckan@anadolu.edu.tr
} 
incelenmiştir. Transatlantik pazarın büyüklüğ̈̈ hakkında fikir vermesi amaclyla taraflar arasındaki ticaret verilerinin yanı sıra yatırım verilerine de yer verilmiştir. Çalışmanın amacı, yeni başlatılan Transatlantik Ticaret ve Yatırım Ortaklı̆̆ı'nın var olan ilişkiye yeni boyutlar ve açılımlar mı kazandıracağını, yoksa mevcut duruma yeni bir görünüs mü vereceğini sorgulamaktır. Çalışmada kullanılan yöntem, Transatlantik Ticaret ve Yatırım Ortaklı̆̆ı'nı tam anlamıyla değerlendirebilmek amacıyla belli başlı ticari anlaşmazlıkları da dikkate alarak taraflar arasındaki ticari ilişskileri belirlemek ve değerlendirmektir.

Anahtar kelimeler: Avrupa Birliği, Amerika Birleşik Devletleri, Avrupa Birliği Amerika Birleşik Devletleri İlişkileri, Transatlantik Ticaret ve Yatırım Ortaklı̆̆l

\section{Introduction}

In the long history relations between the European Union (EU) and the United States (US), the Cold War era constitutes a distinctive age. Following the Second World War, the US acted as a mentor to the Europe both in the economic and political affairs via the instrument of the Marshall Plan. Soon after the EU's fast economic recovery, trade disputes appeared between the parties arising from trade protectionism. Then, the initiatives for a closer economic cooperation started in 1990s not only to prevent the accelerated trade disputes between the EU and the US, but also to diminish the negative welfare effects of trade protectionism on the world economy as a whole. After a series of initiatives and declarations, negotiations for a more vigorous relationship, named as the Transatlantic Trade and Investment Partnership (TTIP), was launched in July 2013, based on the recommendations of the High Level Working Group on Jobs and Growth on February 2013 (The High Level Working Group on Jobs and Growth, 2013).

This article inquiries into the particularities of the TTIP and it is structured as follows: In the first part of the article, trade relations between the EU and the US after the Second World War are examined with the consideration of their main trade disputes. Besides the trade issues, the initiatives for a closer economic cooperation taken before the TTIP are also evaluated. Then, the negotiations on the TTIP are addressed. In the second part, a macroeconomic analysis of the TTIP is provided, concentrating mainly on the bilateral trade and foreign direct investment flows. Along with the statistical data, the effects of the barriers on the trade and the foreign direct investment flows between the EU and the US are also assessed.

\section{Trade Relations Between the European Union and the United States: From Economic Protectorate to Partnership}

The economic and political relations between the EU and the US have a very long and important background and they are subject to many comprehensive 
history books, theses and papers in economics and politics. However, this paper limits its examination with the post- Second World War era and the trade relations between the parties. Trade relations after the Second World War are examined in three sub-sections. In the first sub-section, the economic protectorate years are evaluated in general. In the second sub-section, the trade disputes between the parties are highlighted together with the various attempts and initiatives for a closer economic cooperation. The negotiations on the TTIP agreement are assessed in the last sub-section.

\subsection{Relations within the Era of Economic Protectorate: 1947-1960}

The US emerged from the Second World War as the strongest military and economic power. The leaders of the US were aware of the fact that it had global responsibilities which could not be evaded; as well as its own security and economic interests. Henry L. Stimson' following statement can be cited as a reflection of the perceptions of the Americans on the responsibilities of the US towards the European countries: "We Americans face a challenging opportunity, perhaps the greatest ever offered to a single nation. It is nothing less than a chance to use our full strength for the peace and freedom of the world [...] The troubles of Europe and Asia are not other people's troubles, they are ours" (Stimson, 1947: 57).

In March 1947, President Harry Truman outlined the US commitment to the Western Europe known as the Truman Doctrine. The Truman Doctrine was a pledge of American support for the freedom of the peoples. It opened up a new phase in US foreign policy giving it a new safeguarding mission. However, this mission would be more efficient and the pledge of support would be more certain if the European countries themselves had a stronger economic structure and performance. Nevertheless, the Truman Doctrine did not provide such a broader scope. A new and a broader economic recovery plan was needed to meet the deficiencies of the Western Europe (Urwin, 1991: 15-16).

Before examining the economic recovery plan, it would be helpful to have an overview of Western European economy after the Second World War. Certainly, wartime economic destruction was extensive. For example; 1.8 million buildings were damaged and nearly one-quarter of them were "beyond repair"; 115 railroad stations were "severely damaged or destroyed", and most of the farmlands "transformed into dangerous minefields" in France (Eichengreen, 2007: 54). "Eighty five percent of Italy's merchant marine had been destroyed besides of its railway capacity, industrial plant and equipment" (Eichengreen, 2007: 54). In "Germany, most of the buildings were severally damaged"; almost its entire rail network had become of order (Eichengreen, 2007: 54-55).Furthermore, industrial production decreased dramatically (Eichengreen, 2007: 55). 
The commitment for a European Recovery Program was proposed by the Secretary of State, George C. Marshall on June 1947. He suggested that the US was ready to consider a comprehensive program of economic assistance for European recovery. According to him, European economies suffered from severe problems, deteriorated prewar trade patterns had not been improved and European countries were unable to pay for the importation of food and other necessary commodities. Marshall assumed that the US assistance would break the vicious cycle of decline and restore the confidence of the European people in the economic future of their own countries and of Europe as a whole (Jackson, 1979: 10431044).

There have been various interpretations of Marshall's suggestions. Some of the interpretations described the Marshall's suggestions as a symbol of US generosity and humanitarianism and as a cornerstone in the developing Cold War era (Osgood, 1953; Price, 1955). Some other interpretations accepted the suggestions as a need of US capitalism to save itself by controlling and channeling Europe's economies (LaFeber, 1967; Freeland, 1972). Furthermore, a few of them assumed the suggestions as a bureaucratic way of solving the military occupation of Germany (Gimbel, 1976).

The financial aid allocated by the Marshall Plan was generous. The Plan devoted 15 billion dollar over five years to sending food and providing grants and loans to rebuilt Europe at a time when the American GDP was 250 billion dollar a year (Walker, 1997: 24-25). The Marshall Plan was successful in many respects. The industrial production rose by 62 percent in two years in the Western Europe as a whole (Walker, 1997: 24-25). West Germany's foreign trade doubled between 1949 and 1950 and the country's steel production increased to 14.5 million tons in 1953 when it was 2.5 million tons in 1946 (Walker, 1997: 24-25). Along with the extraordinary recovery in industrial production in West Germany, the signs of the recovery were modest in Britain, France and Italy.

Apart from the financial aid, the Marshall Plan also gave impetus to a prospective European integration. In 1949, the Organization for European Economic Cooperation (OEEC), the body which implemented the Marshall Plan, delivered a new plan for the integration of the European economy. According to the plan, which is usually referred to as the Hoffman Plan, integration of the European economy was not just an idea but a practical necessity (Walker, 1997: 24-25).

Soon after the establishment of the European Economic Community (EEC), barriers on the free flow of international trade became one of the controversial issues between the EEC and the US. The 1950s witnessed a steady increase in the tariffs of the European countries, such as France, Germany and Italy, which 
decided to sustain further protection of their domestic producers. Throughout the 1950s, the European countries and the US could not agree on the balance of trade concessions because both sides preferred the protectionist status quo (Dür, 2008: $655)$.

On the other hand, the prospect of a loss of market access was particularly an issue of concern for the US exporters because the EEC consisted of almost onethird of the US exports in 1958 (Krause, 1968). The probability of a trade diversion after the establishment of the EEC was one of the most threatening issues for the US, as well as for the other non-member countries. According to Piquet, Kreinin and Benoit, the US exports of electrical and industrial machinery, machine tools, certain chemicals and cars would likely suffer from trade diversion (Piquet, 1958: 133; Kreinin, 1959: 618; Benoit, 1961: 172).

Alongside of the prospect of a loss of market access and negative economic effects of trade diversion, the Common Agricultural Policy (CAP) which was launched by the EEC in 1962 also increased the tensions in the US with the anticipation of further welfare losses. The prospect of the United Kingdom's accession to the EEC increased the worries of the US; mainly due to the consideration of the possibility of accompanying preferential trade arrangements with the Commonwealth countries (Dür, 2008: 656). The CAP has been the most comprehensive policy of the EEC, introducing variable levies on various goods with the aim of restricting agricultural imports to maintain the commodity prices set by the EU in advance. In sum, the EEC and the US entered the 1960s with the probable as well as new-born Atlantic trade disputes in their agenda.

\subsection{Relations in the Era of Trade Disputes and Closer Economic Cooperation Initiatives: 1960-2013}

The 1960-2013 period is characterized by various trade disputes between the $\mathrm{EC} / \mathrm{EU}$ and the US alongside the attempts for a closer economic cooperation between the parties. The disputed trade issues and increased economic interdependence paved the way for the search for a closer, structured and institutionalized economic relationship in 1990s. The main reason of the trade disputes in the 1960-2013 period were the protection on agricultural goods and non-agricultural sectors.

\subsubsection{Main Trade Disputes: Protection on Agricultural Goods}

The 1960s were the years of trade disputes between the EEC and the US, and the main disputed issue was the CAP of the EEC. In most cases, the US claimed that the CAP of the EEC was infringing the rules of the General Agreement on Tariffs and Trade (GATT). On the other hand, the EEC defended the CAP as being an internal policy without any international trade effects (Swinbank, 2005: 70). 
The first remarkable trade dispute between the parties was in 1962. The US complained about the quantitative restrictions on products for which France and Italy had granted tariff concessions GATT Dillon Round. This was the first GATT legal complaint by the US against the EEC. It might be argued that the primary aim of these complaints was to warn the EEC against further expansion of the CAP. The US waiver had set a precedent for the EEC to protect and support farm incomes under CAP and the complaints against France and Italy were settled with promises of trade liberalization on some certain products.

The most well-known trade dispute between the EEC and the US was on poultry exports and is usually referred to as the "chicken war" of 1961-1964. The reason of the chicken war was the European Commission's suspension of all of its GATT tariff bindings on variable levy products. Although this kind of a withdrawal was legally permitted, the European Commission was required to pay compensation in the form of tariff concessions on the other products. However, the countries were free to implement their own trade restrictions if they did not find the new tariff concessions adequate.

The reason of the chicken war was the US's refusal of the compensation offered for Germany's withdrawal from the GATT binding on poultry. The US declared that it would retaliate by withdrawing of its own concessions that equaled to 44 million dollar worth of European Community (EC) trade and retaliated by boosting tariffs to some EU exports of agricultural commodities (Hudec, 1988: 26). Hence the chicken war was under way. The EC declared the retaliation as an unbalanced one and the dispute was submitted to the GATT Panel. The chicken war ended after the decision of the GATT Panel for a retaliation of 26 million dollar (Hudec, 1988: 26-27).

In 1970s, the EC initiated a new policy referred to as the Global Mediterranean Policy that included various trade concessions to the Mediterranean neighboring countries. These trade concessions, which included tariff reductions in industrial products and favors in agricultural imports, caused trade disputes between the EEC and the US.

Trade disputes between the EC and the US began with the EC's tariff preferences on citrus products granted to favor of the Mediterranean exporters. The dispute was settled down with an agreement on seasonal tariff concessions on US citrus exporters. Actually, this citrus problem brought a political settlement in 1970s, referred to as Casey-Soames agreement between the parties on the EU's trade preferences initiatives to the Mediterranean and African countries (Hudec, 1988: 28).

The citrus problem arose in 1980s once again and the US, which had a right for compensation imposed higher import duties on pasta imported from the EC. As a 
response, the EC retaliated by increasing the import duties on nuts and lemons imported from the US. The EC and the US solved the problem, known as the 'pasta case' bilaterally, by signing an Agreement on Pasta, and the EC accordingly reduced its subsidies on pasta (Swinbank, 2005: 71).

In 1980s, dispute on the hormones in beef was one of the most controversial trade disputes between the EC and the US. The EC prohibited the import of meat and meat products from the US claiming that the livestock were treated with certain hormones. Thus, the dispute on the hormones has affected the relations between the parties since 1988 when the EU banned imports of beef treated with certain growth-promoting hormones. In 1996, the US took the EC ban to the World Trade Organization (WTO) dispute settlement system. The WTO dispute settlement system gave the US the right to impose trade sanctions on the EC exports. The EC exports which were affected by the sanctions were bovine and swine meat products, Roquefort cheese, chocolate, juices, jams and fresh truffles. The dispute on the hormones in beef had continued for years. The final agreement which was concluded in May 2009 provided for a gradual reduction in US sanctions on EU products and a gradual increase in the EU tariff quota for high quality hormone-free beef (European Parliament, 2012).

Nevertheless, the longest trade dispute in history as the EU itself acknowledges was the banana dispute. The banana dispute or as usually referred the 'banana war' had continued for twenty years. The reason of the banana dispute was the EC banana import regime. The import regime provided preferential treatment for bananas imported from the former colonies of some EC member states, mostly from the Africa and Caribbean and Pacific. The Lóme Convention provided the preferential access to the EU market for the exports of the African and Caribbean and Pacific countries in order to give assistance to their economic development. On the other hand, the US together with several Latin American countries argued that the banana import regime of the EU was dampening their domestic producers.

The banana dispute continued for twenty years and finally ended on November 2012 with an agreement signed between the EU and Latin American countries, settling the longest-running series of disputes in the history of the multilateral trading system (WTO, 2012a). The Geneva Banana Agreement (WTO, 2009) was agreed by the EU, the Latin American countries and the US in December 2009. Since then, the legal requirements like the ratification of the Agreement by each country and the EU's legislation for the implementation had come to an end and the Geneva Banana Agreement is a multilateral agreement now, just like the other WTO multilateral agreements. The trade disputes on the agricultural goods continued in 2000s. The DS 174 - EC - Protection of Trademarks and Geographical Indications for Agricultural Products and Foodstuffs (WTO, 2005a) and DS166 - US - Definitive Safeguard Measures on Imports of Wheat Gluten 
from the EC (WTO, 2000) and DS291 - EC - Measures Affecting the Approval and Marketing of Biotech Products (WTO, 2006a) can be given as example cases.

Besides the above-mentioned examples, trade in the genetically modified (GM) foods also constitutes a significant problem between the EU and the US. The problem arises because of the different regulatory regimes on the GM foods within the EU and the US (Lester, Barbee, 2013: 855). The EU relies on what it refers to as the precautionary principle which means that the EU requires significant evidence before approving new products. Thus, the EU producers have to demonstrate the safety of the GM crops and food products before they can be approved for sale and clearly label contents of the food which contains more than 0.9 percent GM ingredients (European Parliament and the Council, 2003a; European Parliament and the Council, 2003b). On the other hand, the GM foods are considered as equivalent with the unmodified foods and products in the US and thus there is no additional oversight in the absence of scientific proof that any harm is caused by their sale or consumption (Kysar, 2004: 557).

The assessment of Echols (Echols, 1998: 526) might constitute a brief conclusion on the trade disputes on the agricultural goods between the EU and the US. According to Echols, strong domestic influences on food and dietary practices still remain in especially Europe despite the globalization on the food industry and trade. The culture and attitudes of European citizens have tended to favor traditional foods and minimal processing and being skeptical to the new technologies. This skepticism has slowed the EU's broader regulatory process as well as some governmental approvals within the EU. On the other hand, Americans have been keener to accept the new technologies but skeptical of some traditional production techniques. Certainly, these differences in the approaches create regulatory and market access problems due to the time lag. The US which is the faster part in the approval and implementation of a new technique, expects to have the opportunity to enter the EU market without local competition.

\subsubsection{Main Trade Disputes: Protection on Non-Agricultural Sectors}

Apart from the agricultural disputes, the trade dispute on carbon steel was an exemplary case of the trade relations between the EU and the US. The dispute began in 2002 with the US's imposition of safeguard measure on steel. Actually, the trade dispute on steel had domestic political roots in the US. During the presidential election campaign in 2000, George W. Bush promised to help to the domestic steel producers. Thus, the imposition of safeguard measure can be regarded as an attempt to guarantee the elections when the roles of steel producing States were considered (Read, 2005: 136).

The imposition of safeguard measures on steel not only affected the EU but also Japan, Korea, China, Switzerland, Norway, Brazil and New Zealand. 
However, the world-wide concern was on the dispute between the EU and the US. The EU responded to the safeguard measures immediately with an announcement that a retaliatory action would be taken to protect the EU steel industry. The EU imposed temporary safeguard measures in this respect to its steel imports. These measures were product-specific and comprised of a tariff quota (Read, 2005: 161). The WTO Panel concluded in May 2003 that the safeguard measures imposed by the US were inconsistent with the GATT 1994 and the Agreement on Safeguards (WTO, 2003a).

This resolution could be considered as a relatively fast conclusion when compared with the past ever-lasting disputes. The world very welcomed this speedy resolution as the parties avoided a new potential trade war that could damage the international trading system as well as the credibility of the WTO and its Panel decisions.

Apart from the steel dispute, the most well-known and long-lasting nonagricultural trade dispute between the EU and the US was in aerospace sector. The main reason of the trade dispute in aerospace sector was the subsidies of both the EEC and the US to their domestic industries. Actually, the dispute began in 1974 with the entrance of the Airbus, the European aerospace company to the market. Airbus is a government-based consortium of companies from France, Germany, Great Britain and Spain. Airbus had been subsidized for almost two decades and developed its first aircrafts in 1990s. By 1990s, it had captured about one-third of the world market for large commercial jets. It had succeeded to close the technological gap with the Boeing, the leading US producer and became the second largest aircraft producer of the world, replacing the McDonnell Douglas of the US. Meanwhile the McDonnell Douglas was facing a probable bankruptcy (Tyson, 1992: 155-156).

The US had to respond to the Airbus challenge in order to prevent job losses and unemployment in the domestic aerospace sector. On the other hand, the EC justified the government subsidies that served for the development cost of the first Airbus output, the A-300 with the infant-industry argument and the US monopoly in the aerospace sector. After almost two decades with conflicts, the EU and the US reached a bilateral agreement on trade in large civil aircraft in 1992. The agreement regulated various forms of government financing used in the aerospace sector. It also provided several measures restraining government subsidies on the launch of a new aircraft. Moreover, the agreement gave parties the right to monitor the implementation of the agreement (Pavcnik, 2002: 741-742).

The bilateral agreement on trade in large civil aircraft agreed in 1992 had more or less decreased the disputes in the aerospace sector until the launch of Airbus A380 which directly challenged Boeing 747 . Then the US questioned whether the 
EU subsidies for the development of A-380 were compatible with the 1992 agreement and the WTO subsidy agreement. The borrowing terms of the production of A-380 were compatible with the 1992 agreement. However, the US claimed that the financing did not comply with the WTO Agreement on Subsidies and Countervailing Measures that was considered as having precedence over the 1992 agreement (Pavcnik, 2002: 744).

In 2004, the US unilaterally withdrew from the 1992 Agreement and filed a WTO challenge to all the EU support given to Airbus. It requested formal WTO consultations with the EU regarding subsidization of Airbus by the EU. Upon the request of the US, a WTO Panel was set up. The timing of the withdrawal from the 1992 agreement was striking. It coincided with the time right as Boeing was about to lose its leading market share in the aerospace sector. As a response, the EU requested immediately to start the WTO dispute settlement procedure against the US subsidies directed towards Boeing.

The WTO Dispute Settlement Body established a Panel in July 2005. It took almost five years to decide on the Report. Finally, the WTO Panel Report was circulated to the parties on 30 June 2010 (WTO, 2010). The Panel Report was from a neutral perspective without clear winner or loser even though both the Airbus and the Boing announced victory afterwards (Baskett, 2010: 13-14). After the circulation of the Panel Report to the parties, both the EU and the US appealed to the WTO again citing certain issues of the rulings. Then, the Appellate Body Report was circulated to the parties in May 2011 (WTO, 2011).

The Appellate Body upheld the WTO Panel's finding that certain subsidies provided by the EU and certain EU member state governments to Airbus are incompatible to the Article 5 (c) of the Agreement on Subsidies and Countervailing Measures ${ }^{1}$ because they have caused serious prejudice to the interests of the US. On the other hand, a separate dispute brought by the EU against the US for subsidies allegedly provided to Boeing is currently before the Appellate Body (WTO, 2012b). Hence, the history of the trade dispute in the aerospace sector so far justifies a never-ending story of the leading actors.

Apart from the disputes on steel sector and aerospace sector, there are various trade disputes between the EU and the US. Some of them are the DS165 - US Import Measures Imposed by the US on Certain EC Products, DS176 - US -

\footnotetext{
${ }^{1}$ Article 5 of the Agreement on Subsidies and Countervailing Measures: No Member should cause, through the use of any subsidy referred to in paragraphs 1 and 2 of Article 1 , of adverse effects to the interests of other Members, i.e.: a) injury to the domestic industry of another Member; b) nullification or impairment of benefits accruing directly or indirectly to other Members under GATT 1994 in particular the benefits of concessions bound under Article II of GATT 1994; c) serious prejudice to the interests of another Member. This Article does not apply to subsidies maintained on agricultural products as provided in Article 13 of the Agreement on Agriculture.
} 
Section 211 Omnibus Appropriations Act of 1998 (WTO, 2002), DS212 - US Countervailing Measures Concerning Certain Products from the EC (WTO, 2005b), DS217 - US - Continued Dumping and Subsidy Offset (WTO, 2003b), DS294 - US - Laws, Regulations and Methodology for Calculating Dumping Margins (Zeroing) (WTO, 2007) and DS315 - EC - Selected Customs Matters (WTO, 2006b).

When the trade disputes in recent years are examined broadly, it is understood that most of them are related with the non-tariff barriers especially in the form of regulatory issues. Thus, the regulatory convergence as well as regulatory cooperation should constitute the core element of a closer economic cooperation between the EU and the US.

\subsubsection{Initiatives for a Closer Economic Cooperation before the Transatlantic Trade and Investment Partnership}

The EU and the US share a very dynamic, mutually beneficial economic relationship consisting of about 12 percent of the world's population and approximately 50 percent of the world's gross domestic product despite various trade disputes. In spite of the rise of the Asian economies, with China as the leading country, trade and investment relations between the EU and the US are still considerably high. Thus, a closer trade and investment partnership would not only affect the parties but also the world economy as a whole.

Although the trade and investment relations between the EU and the US have always been important in the past decades, 1990s was a very pivotal era. There were several reasons for upgrading the relations. The end of the Cold War by itself was precisely a very important and strategic factor. In 1990, the US proposed a Transatlantic Declaration to reaffirm the solidarity between the EC and the US after the collapse of the Soviet Union. Although the Transatlantic Declaration mainly focused on security issues, there was an increased emphasis on the economic aspects. The completion of the European Internal Market by 1992 could be considered as another important factor that reinforced upgrading of the relations. The US could not remain indifferent to the world's largest internal market as the biggest trade and investment partner of the EU.

Moreover, increased trade and investment relations between the EU and the US have created new demands for an increased market access. However, in 1990s, both European and American multinational companies identified various regulatory frameworks for goods and services as the most important barriers to international trade between the parties. The standards, testing and verification procedures are deemed as far more harmful and costly than the tariffs and quotas. As such, these regulatory frameworks are regarded as the non-tariff barriers to the Transatlantic trade. By decreasing the differences in the regulatory issues and 
harmonizing the framework, both the EU and the US hope to benefit via reducing the costs and increasing the competitiveness of the Transatlantic economy (Ahearn, 2011: 4).

The initiatives in 1990s for closer trade and economic partnership could also be interpreted with a pragmatic approach. After the successful completion of the longlasting Uruguay Round, it seemed logical that the two leading economies of world trade could work together to resolve their existing trade problems and in this process be a role model to be pursued by the rest of the world. In this way, they would help the acceleration of the progress towards a freer world trade (Schott, Oegg, 2001: 745).

Actually, institutionalizing the economic relations between the EU and the US has always been on the political as well as economic agenda of the parties. However, there has been a shift from traditional trade policy issues like decreasing the import tariffs or quotas to the issues like increased and secured market access and harmonizing trade-related domestic policies (Langhammer, Piazolo, Siebert, 2002: 161).

The process of institutionalization of the relations began on 27 February 1990 with the Transatlantic Declaration which aimed to establish an institutional framework for regular and intensive consultation between the parties. The Declaration foresaw biannual EU and US Summit meetings and specified three major areas to cooperate, namely economic liberalization, cooperation in education, science and culture, and cooperation in combatting against international crime, terrorism and environmental degradation.

Although the Transatlantic Declaration specified crucial cooperation areas, the cooperation instruments and procedures were not specified explicitly. Thus, the Declaration soon required new, supplementary agreements or protocols to clarify the cooperation process. In this context, the New Transatlantic Agenda was signed in 1995 which identified four priority areas for closer cooperation. These areas were: promoting peace and stability, democracy and development around the world, responding to global challenges, contributing to the expansion of world trade and promoting closer economic relations, and, building bridges across the Atlantic among business people, scientists, the academia, and so on.

Alongside the New Transatlantic Agenda, the EU and the US also adopted a Joint Action Plan which specified some specific policy areas where deeper cooperation could be attained. The most ambitious policy area in the Joint Action Plan was about strengthening of the multilateral trading system and liberalization of the international trade. It also established a new governance system for the relations besides the EU/US Summit, namely the Senior Level Group and the New Transatlantic Agenda Task Force. Nevertheless, the most promising part of the 
Joint Action Plan was the plan to establish a new transatlantic marketplace through enhanced regulatory cooperation without any mention of a free trade area (Pollark, 2003: 5-9).

The Plan was provided with a substance in March 1998 in a European Commission Communication (European Commission, 1998) without an explicit mention of a free trade area at least for trade in goods. Although a proper definition of the transatlantic marketplace was not made in the proposal, the elimination of the tariffs on industrial goods by 2010 was planned. On the other hand, the proposal foresaw a free trade area for trade in services. But the European Commission's initiative for the establishment of a transatlantic marketplace failed because of the French veto.

Meanwhile, the trade disputes between the EU and the US continued in 1990s despite the Transatlantic Declaration and Joint Action Plan. A firmer commitment was needed to settle the trade disputes between the parties like the disputes on bananas, the aerospace sector and so on. Thus, the parties agreed on a Transatlantic Economic Partnership in May 1998 which aimed to abolish the bilateral regulatory barriers to trade and to determine common positions on the WTO negotiations. The Transatlantic Economic Partnership was different than the proposal for the transatlantic marketplace in many respects. It set up a mechanism of regular dialogue in order to sustain closer cooperation and it contained many proposals to examine and compare the policies of the parties (Hindley, 1999: 4546). The parties agreed on an Action Plan which identified areas for common actions both bilaterally and multilaterally with a timetable for their achievement. (Transatlantic Economic Partnership: Action Plan, 1999: 24).

The initiatives in 2000s to strengthen the relations between the EU and the USare examined thoroughly, it is seen that they had primarily focused on the issues of securing market access and harmonizing trade related domestic policies without mentioning a free trade area or a transatlantic marketplace.Thus, following the acceptance of the Transatlantic Economic Partnership Action Plan, a Steering Group as well as specialized working groups on specific issues of the Action Plan such as the Working Group on Technical Barriers to Trade and Working Group on Food Safety, were set up.

The initiatives for the further development of the transatlantic relations gained an impetus with the Germany's Presidency of the EU during the first half of 2007. In the EU Presidency Statement (German Presidency of the European Union, 2007) on the Transatlantic Relations to the Plenary of the European Parliament on 25 April 2007, it was stated that strengthening of joint transatlantic action and developing the EU's relations with the US, both in policy making and business and in energy security and climate protection were among the central objectives of the 
German Presidency. According to the Presidency, the different regulatory approaches both in the EU and the US had been producing a heavy burden of transaction costs, and thus, a further elimination of the non-tariff barriers was needed. The core of the initiative was a mutual political commitment to deepen cooperation with a view to achieve regulatory convergence and a further intensification of economic links (German Presidency of the European Union, 2007).

A significant success of the German Presidency was the agreement on the Framework for Advancing Economic Integration between the EU and the US at the EU-US Summit on 30 April 2007 (European Union External Action, 2007). Moreover, the parties established the Transatlantic Economic Council to oversee the efforts outlined in the Framework. Nevertheless, while the parties were negotiating on the Framework for Advancing Economic Integration between the EU and the US and agreeing on a Transatlantic Economic Council, the BoingAirbus dispute was on the agenda of the WTO.

At the EU-US Summit in November 2010, the parties tasked the Transatlantic Economic Council to strengthen the transatlantic economic ties by promoting innovation, streamlining regulations and eliminating barriers to trade and investment. The parties underlined the importance of generating new opportunities for jobs and growth (European Commission, 2011). At the November 2011 Summit, the parties established the High Level Working Group on Jobs and Growth.

\subsection{Negotiations on the Transatlantic Trade and Investment Partnership Agreement}

The High Level Working Group on Jobs and Growth which was established to identify policies and measures to increase the trade and investment between the EU and the US to support mutually beneficial job creation, economic growth and international competitiveness issued its interim report on 19 June 2012 (The High Level Working Group on Jobs and Growth, 2012). In its interim report, the High Level Working Group reached the preliminary conclusion that a comprehensive transatlantic trade and investment agreement would be the option with the greatest potential for supporting jobs and promoting growth and competitiveness across the Atlantic.

The High Level Working Group concluded in its final report (The High Level Working Group on Jobs and Growth, 2013) "that a comprehensive agreement that addresses a broad range of bilateral trade and investment issues, including regulatory issues, and contributes to the development of global rules would provide the most important mutual benefit of the various options they have considered. The co-chairs of the parties recommended to the leaders that each party initiate as soon 
as possible the domestic procedures to launch the negotiations on a comprehensive trade and investment partnership.

On the basis of the recommendations of the High Level Working Group, the US President Barack Obama, European Council President Herman Van Rompuy and European Commission President José Manuel Barroso announced on 13 February 2013 that they would initiate the internal preparations for the launch of the negotiations (European Commission, 2013a). Thus, backed with a long period of preparations, the first round of negotiations for the TTIP agreement began on 8 July 2013 in Washington and ended on 12 July 2013. The sixth round of negotiations will begin on 13 July 2014.

Regarding the scope of the negotiations, the negotiating groups have set out respective approaches and ambitions in as much as twenty various areas that the TTIP is set to cover at the first round of negotiations. They included market access for agricultural and industrial goods, government procurement, investment, energy and raw materials, regulatory issues, sanitary and phytosanitary measures, services, intellectual property rights, sustainable development, small and medium sized enterprises, dispute settlement, competition, customs/trade facilitation and statowned enterprises (European Commission, 2013b).

The second round of negotiations for TTIP agreement started on 11 November 2013 and ended on 15 December 2013. The parties discussed investment rules, trade in services, energy and raw materials, as well as regulatory issues, technical barriers to trade and sectoral issues. Regarding the investments, the discussions continued on comparing respective approaches to investment liberalization and protection. On services, the parties compared their respective approaches on crossborder services, financial services, telecommunications and e-commerce. Regarding the regulatory issues, both the EU and the US agreed on horizontal rules and specific commitments in sectors. On energy and raw materials, they continued talks on how to develop a common approach to addressing the challenges they both face (European Commission, 2013c).

The third round of negotiations initiated on 16 December 2013 and ended on 21 December 2013. Negotiators made progress on the three main parts of the TTIP, namely market access, regulatory aspects and rules and these were expected to be the main topics of the next round of negotiations (European Commission, 2013d). The fourth round of negotiations began on 10 March 2014 and finalized on 14 March 2014. There was a steady progress in the market access, regulatory aspects and rules. The parties also continued to look for the ways to achieve greater regulatory compatibility in pharmaceuticals, cosmetics, medical devices, automotive and chemicals industries (European Commission, 2014). The fifth round of negotiations started on 19 May 2014 and finished on 23 May 2014. The 
negotiators moved from discussing a conceptual framework to defining specific ideas for addressing the majority of the negotiating areas (Office of the United States Trade Representative, 2014). The last round is the sixth round which will be held on 13 July 2014. These negotiation rounds have constituted important steps for overcoming the obstacles in EU-US trade relations and establishing closer cooperation.US President Barack Obama, European Council President Herman Van Rompuy and European Commission President José Manuel Barroso have also made it clear that reducing regulatory barriers to trade and investment would be one of the most important ways through which the TTIP would help the EU and the US to foster their economies (European Commission, 2013e).

\section{A Macroeconomic Outlook to the Transatlantic Trade and Investment Partnership}

It is apparent from the previous sub-section that the negotiations on the TTIP agreement are on track. Thus, before evaluating the potential benefits of a comprehensive transatlantic partnership, it would be necessary to examine the macroeconomic outlook. To evaluate the Partnership in macroeconomic terms, trade and foreign direct investment flows between the EU and the US are analyzed in this sub-section. Then, the effects of the barriers on trade and foreign direct investment flows between the EU and the US are discussed.

\subsection{Trade and Foreign Direct Investment Flows between the $\mathbf{E}$ and the US}

The trade and investment have always been the essential determinants of the relations between the EU and the US. The two economies constitute roughly half of the world output and trade. Moreover, they are each other's important investment partners.

\subsubsection{Trade Flows}

The trade flows are examined for the 1999-2013 period due to the lack of regular SITC data for the previous years at the Eurostat database. Trade flows between the EU and the US during 1999-2013 can be seen at Figure 2.1. According to the Figure, the EU has a trade surplus on its overall trade with the US. The volume of trade decreased in 2009 , reflecting the negative effects of the global financial crisis in the US in 2008. Nevertheless, it began to increase rapidly after 2010 until 2012. Then, the volume of trade slightly decreased in 2013.

According to Eurostat, the US is the third major import partner of the EU in 2013, constituting almost 11.6 percent of the total imports of the EU from other countries. The biggest import partner of the EU is China with a share of 16.6 percent and Russia is the second with a share of 12.2 percent. The US constitutes the biggest export partner of the EU at the same year having a 16.5 percent within 
the total exports of the EU to the non-member countries. Switzerland and China follows the US with the shares of 9.7 percent and 8.5 percent, respectively.

Figure 2.1: EU Trade with the US (1999-2013)

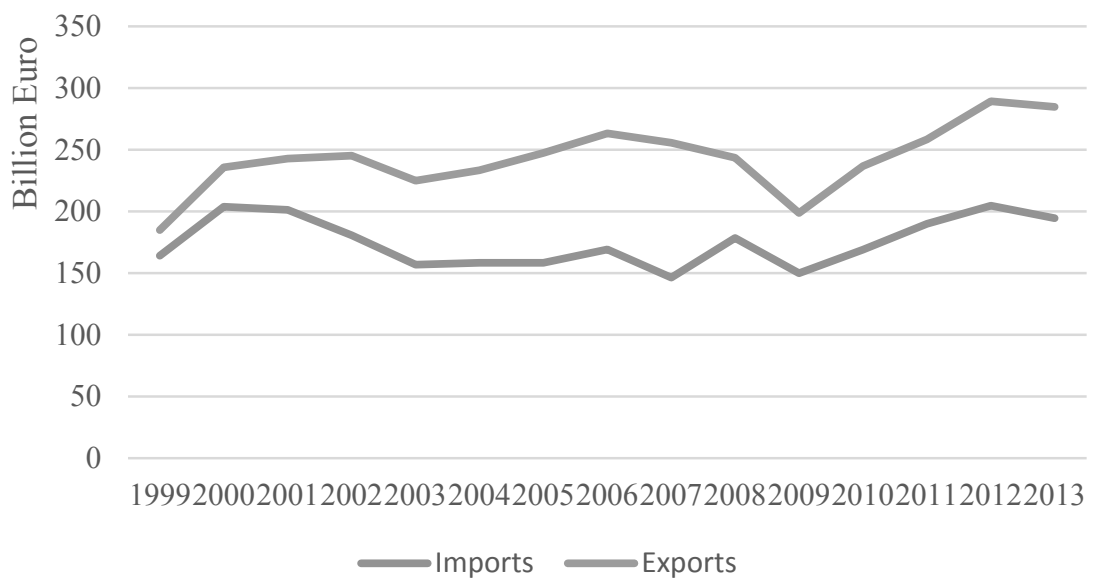

Source: Author's own table based on data from Eurostat (2014).

On the other hand, the EU is the second major import and export partner of the US in 2013 having 15.8 percent within the total imports of the US from the world and 16.5 percent within the total exports of the US to the world. The biggest import partner of the US is China with a share of 18 percent while Canada is the biggest export partner of the US with a share of 18.3 percent.

The data above gives a brief outlook to the dimensions of the trade between the EU and the US. Nevertheless, a detailed data is required so as to analyze the trade flows thoroughly. Thus the trade between the parties by SITC (Standard International Trade Classification) Section is examined at Figure 2.2 and Figure 2.3 so as to understand the characteristics of the international trade. 
Figure 2. 2: Imports of the EU from the US by SITC Section (1999-2013)

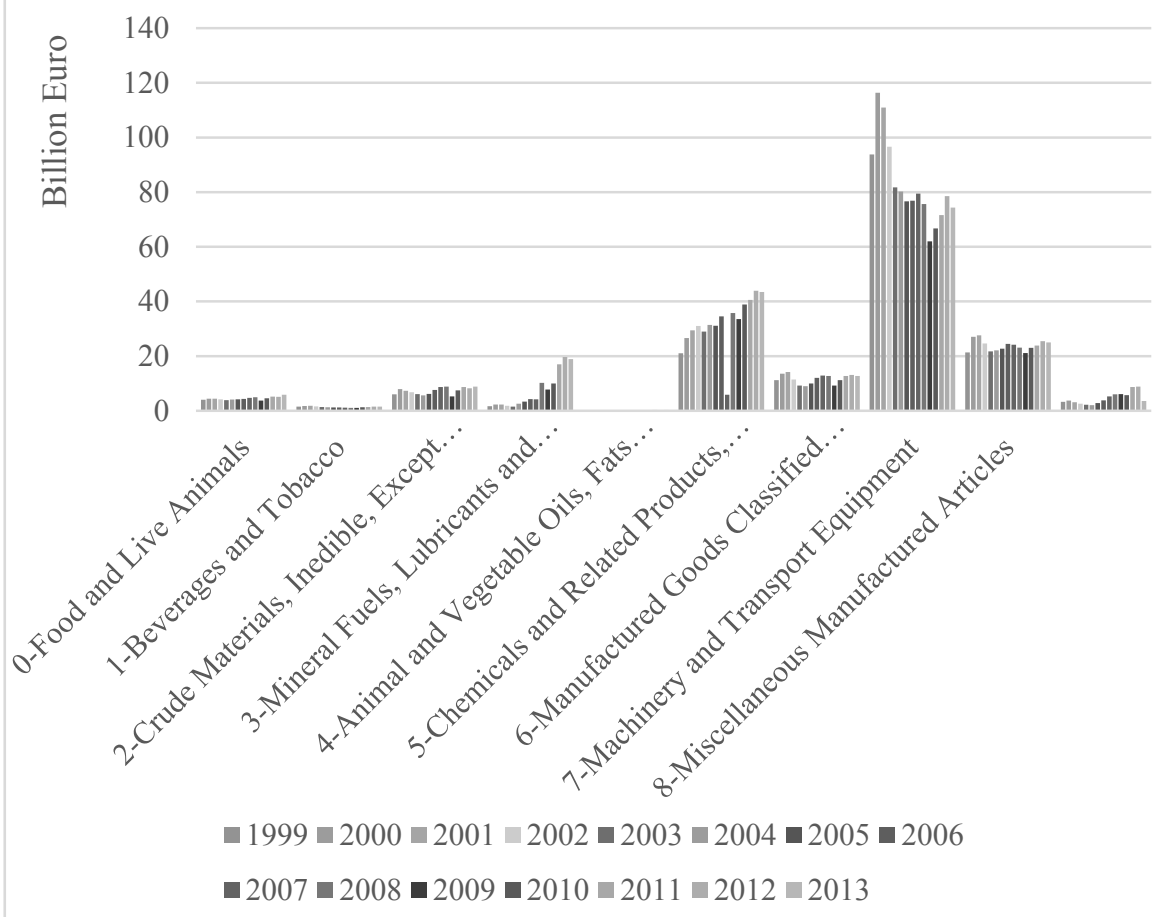

Source: Author's own table based on data from Eurostat (2014)

Figure 2.2 displays that within the imports of the EU from the US by SITC Section during 1999-2013; the biggest share belongs to the Machinery and Transport Equipment despite the decreasing trend after 2000. The decline within the Machinery and Transport Equipment imports starts to increase after 2010. On the other hand, the imports of the Chemicals and Related Products, N.E.S. (Not Classified Elsewhere) has a steady increase except the dramatic decrease in 2007, constituting the second biggest imports of the EU from the US. Miscellaneous Manufactured Articles is the third biggest import Section having a more or less stationary trend.

According to the Figure 2.3, the biggest SITC Section within the exports of the EU to the US is the Machinery and Transport Equipment though its fluctuating trend. Chemicals and Related Products, N.E.S. is following the Machinery and Transport Equipment with a steady increase. The other biggest export Sections are the Miscellaneous Manufactured Articles and the Manufactured Goods Classified 
Chiefly by Material. Depending on the import and export data, it should be remarked that there is an intra-industry trade ${ }^{2}$ especially in the Machinery and Transport Equipment Section as well as in the Chemicals and Related Products, N.E.S. Section and Miscellaneous Manufactured Articles Section.

Figure 2.3: Exports of the EU to the US by SITC Section (1999-2013)

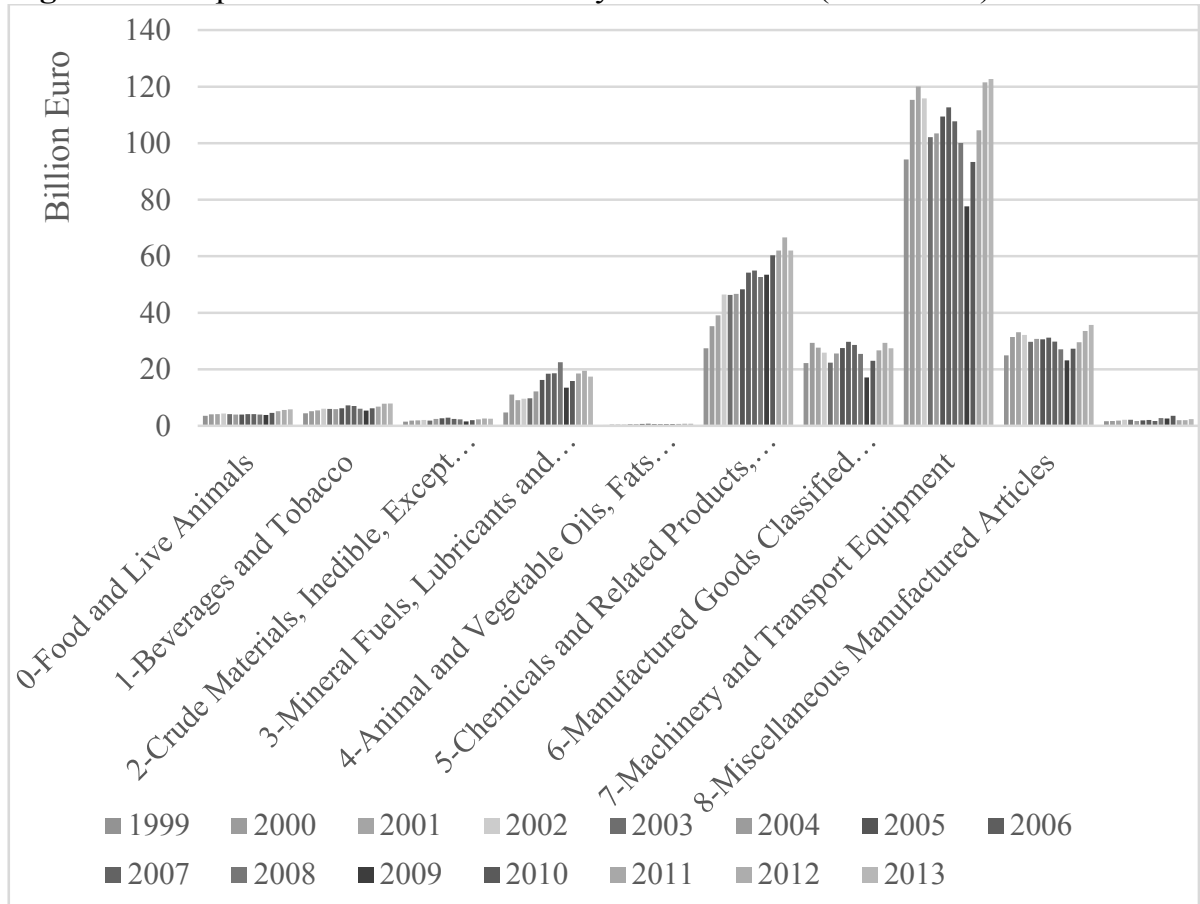

Source: Author's own table based on data from Eurostat (2014)

Intra-industry trade refers to a two-way trade in the same industry or in the differentiated commodities. A large portion of the output of the industrialized economies today involves differentiated rather than homogeneous products. Intraindustry trade arises so as to take advantage of positive economies of scale in production (Salvatore, 2007: 179). The proportion of intra-industry trade within the world trade has steadily grown over the last half-century. Intra-industry trade has a

\footnotetext{
${ }^{2}$ The measurement of intra-industry trade relies on an industrial classification system that categorizes commodities into different industries (Krugman, Obstfeld, Melitz, 2012: 199). The level of intraindustry trade is measured by the intra-industry trade index $(\mathrm{T})$ in which $\mathrm{T}=1-\frac{|X-M|}{X+M}$.
} 
bigger share in the trade of manufactured commodities among industrialized countries accounting the majority of the world trade (Krugman, Obstfeld, Melitz, 2012: 199).

At this point, the intra-industry trade within the above-mentioned SITC Sections requires a queried in terms of the market access conditions for a proper assessment of the TTIP. In that sense, the study of Ecorys (2009) is a leading one in determining the non-tariff barriers imposed on the trade between the EU and the US. Table 2.1 gives a brief summary of the Ecorys main non-tariff barriers findings imposed on the trade between the parties.

According to the Table 2.1 that gives a brief summary of the Ecorys findings, the non-tariff barriers within the Machinery and Transport Equipment Section and the Chemicals and Related Products, N.E.S. Section in which there is the intraindustry trade are relatively high though the classification of the industries does not accurately represents the SITC Sections. Nevertheless, this finding refers to a troubled market access within the industries in which most of the overall trade between the parties is going on and emphasizes the strategic importance of achieving the regulatory convergence within the TTIP.

Table 2.1: Perceived Non-Tariff Trade Barriers Index on Selected Commodities (Index between 0-100)

\begin{tabular}{|lll|}
\hline & EU exports & US exports \\
Machinery Industry & 50.9 & 36.5 \\
Automotive Industry & 34.8 & 31.6 \\
Aerospace and Space Industry & 56.0 & 55.1 \\
Chemicals Industry & 45.8 & 53.2 \\
Cosmetics Industry & 48.3 & 52.2 \\
\hline
\end{tabular}

Source: Ecorys (2009).

\subsubsection{Foreign Direct Investment Flows}

After examining the trade flows between the EU and the US, it would be essential to hold an opinion on the foreign direct investment (FDI) flows which is regarded as one of the fundamental ingredients of the TTIP. Figure 2.4 demonstrates that the US has the biggest share within the extra EU-27 FDI inward stocks during 2001-2012. However, it should be remarked that while the total extra EU-27 FDI inward stocks during 2001-2012 are tripled, the US's share within the inward stocks is only doubled. This finding might refer to some problems relating with barriers on the free flow of the FDI between the EU and the US. 
Figure 2.4: EU Foreign Direct Investment Inward Stocks by Main Partners (billion Euro) (2001-2012)

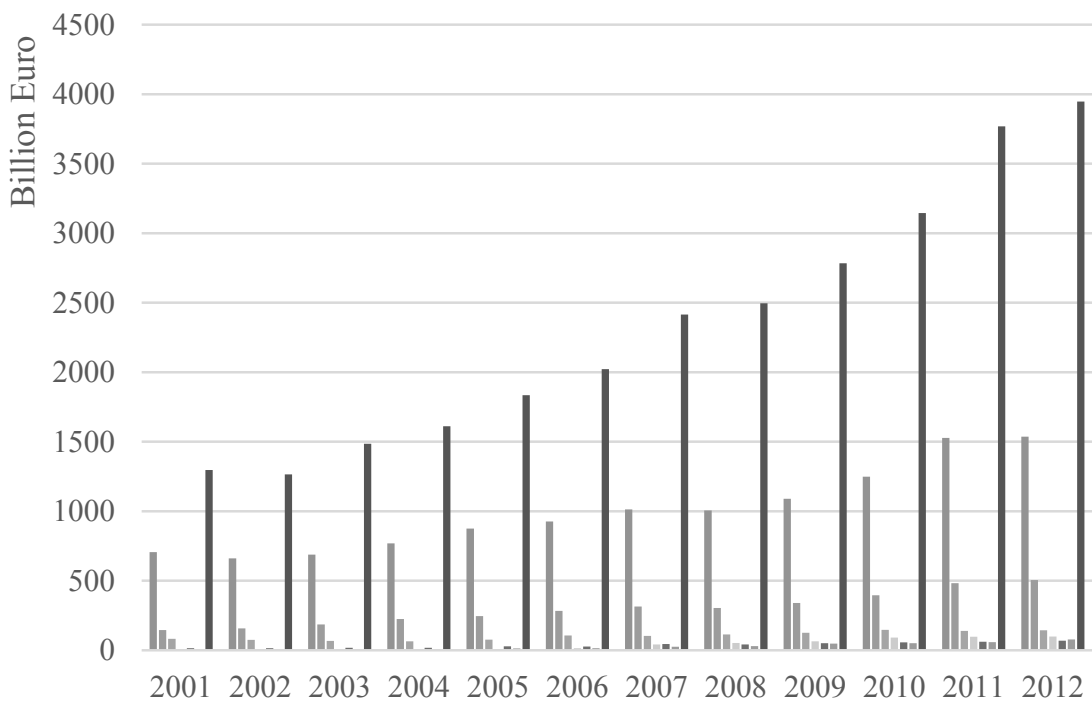

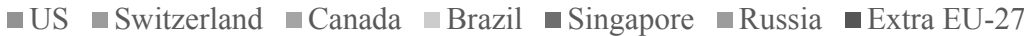

Source: Author's own table based on data from Eurostat (2014)

When the extra EU-27 FDI outward stocks during 2001-2012 are examined from Figure 2.5, the US's leading share is attracting the attendance. However, the increase of the share of the US within the extra EU-27 FDI outward stocks is very low. These findings about the outward FDI stocks together with the findings about the inward FDI stocks trigger to various anticipations like the prominent regulatory barriers on the free flow of the FDI or the loose of the attractiveness of making an investment in the EU and the US. The parties might find it more profitable to invest in another emerging economy. Determining the reasons of the decrease of the FDI shares requires further analysis and analytical examination.

Based on the leading study of the Ecorys (2009), the Centre for Economic Policy Research (CEPR) prepared a Report in 2013 in which it examines the nontariff barriers on the trade and investment between the EU and the US. According to the CEPR Report (2013), the highest non-tariff barriers on the free flow of FDI between the EU and the US are on the aerospace industry, automobile industry, chemicals and cosmetics industry, textiles, clothing, footwear industry, paper and wood products industry and the transportation services. Hence, for a closer Transatlantic economic partnership, the FDI flows between the EU and the US 
should be stimulated via negotiating on the non-tariff barriers imposed on the investments.

Figure 2.5: EU Foreign Direct Investment Outward Stocks by Main Partners (billion Euro) (2001-2012)

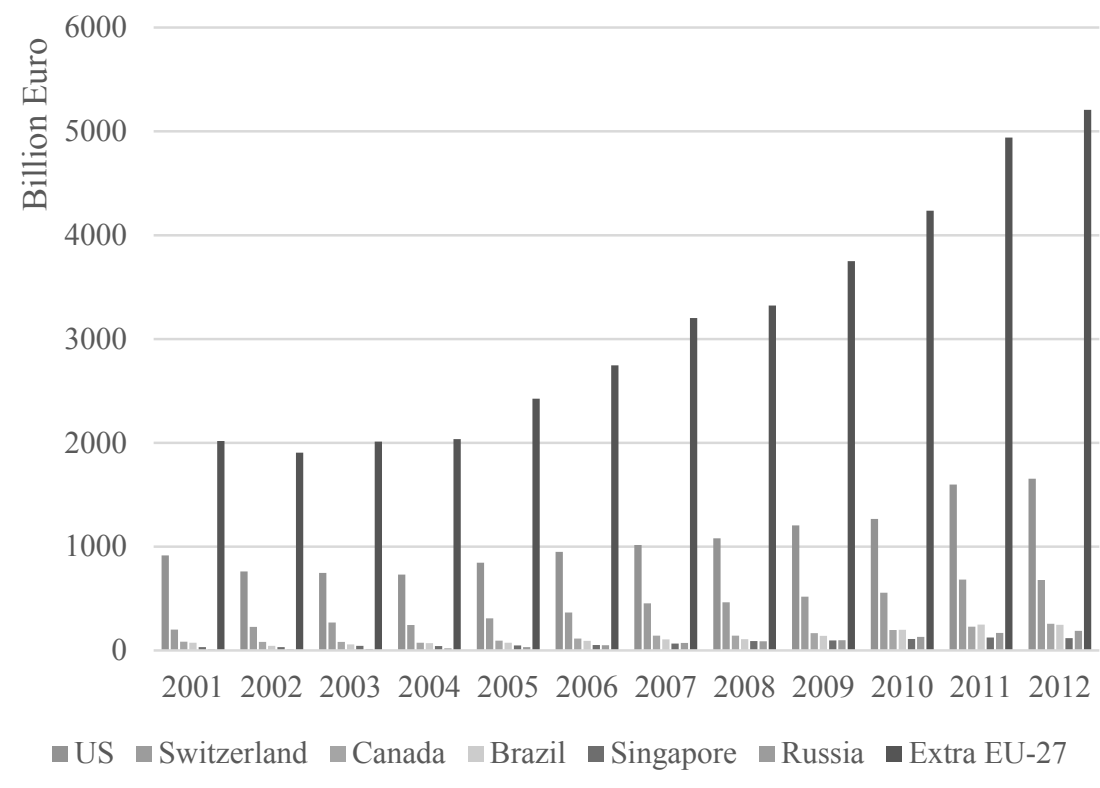

Source: Author's own table based on data from Eurostat (2014)

\subsection{The Effects of the Barriers on Trade and Foreign Direct Investment Flows between the $E U$ and the US}

Upon the start of the talks on the TTIP, many studies have been conducted on the possible economic effects of this partnership. Among them, Felbermayr et. al. (2013) analyzed the effects of the TTIP on Germany based on the assumption that the TTIP would bring the same average trade liberalization effects as previous German free trade agreements with other partners. According to Felbermayr et. al. (2013), the gain for Germany in terms of output is relatively low when compared with that of the US. IFO (2013) found out that with the TTIP, the wages of the unskilled workers in Germany would increase more than the skilled workers. Fontagné et. al (2013) presented results for a reference liberalization scenario and four additional scenarios for the EU-27, the US, the UK, Germany, France and the Eastern European EU countries. Erixon and Bauer (2010) examined only the effects of liberalizing trade in goods. Welfens and Irawan (2014) focused in mainly 
on the sectoral output and employment effects of the TTIP for Germany, the EU and the US.

When the barriers on trade between the EU and the US considered, the tariffs do not constitute an important obstacle on the free flow of trade. According to the Centre for Economic Policy Research (CEPR) Report, the EU imposes 3.5 percent tariff rate on goods as an average while the US imposes 1.5 percent. The EU imposes 14.6 percent tariff rate on processed foods and 8 percent on motor vehicles as the highest tariff rates while the US imposes 3.3 percent and 1.2 percent, respectively (CEPR, 2013: 14). Even though the average tariff rates are relatively low, the non-tariff barriers mostly in the form of domestic regulations constitute a substantive impediment for trade flows. However unlike the tariffs, it is not always easy to abolish the non-tariff barriers when they are used for domestic aims.

Although the importance of the non-tariff barriers on the free flow of trade as well as for investment is definite, it is not so easy to determine them definitely. Ecorys (2009) achieved to gather the data of the non-tariff barriers that are imposed on the transatlantic trade and investment.

According to the Ecorys leading study, the US imposes relatively higher nontariff barriers to services than the EU, highest in communication, construction, travel and transport. When the goods and services sectors are compared in terms of the imposition of non-tariff barriers, it is understood that both the EU and the US protects their goods sectors via non-tariff barriers more than their services sector. Among the goods sectors, the most protected sector is the aerospace and space industry both in the EU and the US. Cosmetics, chemicals, medical measuring and testing appliances, biotechnology and machinery are following the aerospace and space industry. On the other hand, the EU imposes relatively higher non-tariff barriers to the pharmaceuticals, textiles, clothing and footwear, wood and paper and paper products.

As in the case of the determination of the non-tariff barriers, it is also though to identify the macroeconomic effects of an abolishment or at least a reduction of the tariff and non-tariff barriers on the transatlantic trade and investment. The studies in this respect mostly refer to an independent report prepared by the CEPR (CEPR, 2013). This in-depth report gives a detailed outlook of the current transatlantic trade and investment and the barriers on the free flow of them. The study covers an economic modelling ${ }^{3}$ to estimate the potential impact of different policy scenarios.

\footnotetext{
${ }^{3}$ The CEPR study reviews the importance of bilateral economic relationship and provides a computable general equilibrium (CGE) based estimates for the economy wide impact of reducing tariffs and nontariff barriers. The estimates are provided with regards to expected changes in GDP, sector output, aggregate and bilateral trade flows, wages and labor displacement among other issues. The analysis uses the GTAP8 database (projected to 2027) in conjunction with the non-tariff barrier estimates reported in
} 
Furthermore, the study highlights not only the gains of the EU and the US from the so-called partnership, but also the benefits for the world economy as a whole.

The CEPR study examines two different policy alternatives for liberalizing the trade and investment between the EU and the US. The first alternative is the partial agreement alternative that foresees liberalization only in the tariffs, services or procurement. The second alternative is a comprehensive one that stipulates liberalization in the tariffs, services, as well as in the non-tariff barriers on goods and services. The comprehensive alternative has two options: First, a less ambitious liberalization that includes a 10 percent reduction in trade costs arising from the abolishment of the non-tariff barriers and 98 percent tariff removal. Second, an ambitious liberalization includes a 25 percent reduction in trade costs arising from the abolishment of the non-tariff barriers and 100 percent tariff removal (CEPR, 2013).

The summary of the CEPR report on the macroeconomic effects of the liberalization of trade and investment between the EU and the US is given in Table 2.2. As Table illustrates, positive gains for both economies is expected. Nevertheless, it should be recalled the data ought to be interpreted as changes relative to a projected 2027 global economy. Regarding the change in the GDP, the increase in the GDP of the EU is more than the increase in the GDP of the US in all the policy alternatives. Bilateral exports will also increase in all the policy alternatives. The increase is tremendous especially in the comprehensive agreement policy alternative. Notwithstanding, the increase in the EU exports to the US is more than the increase in the US exports to the EU in all the policy alternatives except the limited agreement which has only a tariff reduction. However, the increase within the total exports of the EU and the US in the comprehensive agreement policy alternative is very remarkable. The increase constitutes almost 220 billion euros for the EU and 240 billion euros for the US.

the Ecorys (2009) study. The study investigates different policy options for the deepening of the bilateral trade and investment relations. One of the policy options is limited in scope of barriers addressing only the tariffs only, services only or procurement only. The other policy option concerns a comprehensive liberalization agenda that covers simultaneously tariffs, procurement, non-tariff barriers on commodities and non-tariff barriers on services. 
Table 2.2: Macroeconomic Effects of the Liberalization of Trade and Investment between the EU and the US

\begin{tabular}{|l|c|c|c|c|c|}
\hline & $\begin{array}{l}\text { Limited } \\
\text { agreement: } \\
\text { tariffs only }\end{array}$ & $\begin{array}{l}\text { Limited } \\
\text { agreement: } \\
\text { services } \\
\text { only }\end{array}$ & $\begin{array}{l}\text { Limited } \\
\text { agreement: } \\
\text { procurement } \\
\text { only }\end{array}$ & $\begin{array}{l}\text { Comprehensive } \\
\text { agreement: less } \\
\text { ambitious }\end{array}$ & $\begin{array}{l}\text { Comprehensive } \\
\text { agreement: } \\
\text { ambitious }\end{array}$ \\
\hline Change in GDP & & & & \\
\hline $\begin{array}{l}\text { EU, } \\
\text { million } \\
\text { euros }\end{array}$ & 23,753 & 5,298 & 6,367 & 68,274 & 119,212 \\
\hline $\begin{array}{l}\text { US, } \\
\text { million } \\
\text { euros }\end{array}$ & 9,447 & 7,356 & 1,875 & 49,543 & 94,904 \\
\hline Bilateral exports f.o.b & & 4,591 & 6,997 & 107,811 & 186,965 \\
\hline $\begin{array}{l}\text { EU to } \\
\text { US, } \\
\text { million } \\
\text { euros }\end{array}$ & 43,84 & 2,859 & 3,411 & 100,909 & 159,098 \\
\hline $\begin{array}{l}\text { US to } \\
\text { EU, } \\
\text { million } \\
\text { euros }\end{array}$ & 53,777 & & & & \\
\hline Total exports f.o.b. & & 7,136 & 125,232 & 219,97 \\
\hline $\begin{array}{l}\text { Extra- } \\
\text { EU, } \\
\text { million } \\
\text { euros }\end{array}$ & 43,74 & 5,777 & & & 239,543 \\
\hline $\begin{array}{l}\text { US, } \\
\text { million } \\
\text { euros }\end{array}$ & 57,33 & 5,488 & 5,942 & 142,071 & \\
\hline
\end{tabular}

Note: Estimates should be examined as changes relative to a projected 2027 global economy.

Source: CEPR (2013: 3).

\section{Conclusion}

The history of economic relations between the EU and the US is a very long one with a network of affinities and commitments. But admittedly, the economic relations after the Second World War are the evidences of a unique era in which the foundations of an economic partnership that would comprise the world's largest market are laid down. After the economic protectorate years, the EU became the leading trade and investment partner of the US. However, this special partnership was accompanied by significant trade disputes. The grounds of these trade disputes were the trade protectionism, mostly implemented with regard to the agricultural goods as well as industrial commodities. The implementation of the CAP of the EU by itself constituted the main reason of the trade disputes on agricultural goods. Among the various disputed non-agricultural sectors that were 
not taken into examination in this paper as a whole, the steel sector and the aerospace sector might be referred as the most troublesome ones in terms of trade protectionism. It should be noted that the trade dispute between the EU and the US in the aerospace sector is one of the most complex, long and costly disputes within the GATT/WTO history which has not been properly resolved yet. However, the trade disputes both in the agricultural and industrial goods have still been continuing in 2000s. And not surprisingly, the main disputing issue is the regulatory convergence.

In the meantime, the initiatives for a closer economic cooperation began in 1990s. Actually, the scope of the initiatives was vague, reflecting both the EU's and the US's hesitations on the announcement of an aspired -even dreamytransatlantic free trade area. After the adaptation of the Transatlantic Declaration in 1990, the parties committed themselves with the New Transatlantic Agenda. However, this commitment neither solved the existing trade disputes nor prevented new ones. Thus, the Transatlantic Economic Partnership was announced in 1998 as a further commitment with the aim of facilitating the market access and harmonizing trade related domestic policies without mentioning a free trade area between the parties. The search for a comprehensive and efficient economic relationship has been finalized with the decision on the establishment of the TTIP. The negotiations of this newly-introduced partnership began in July 2013 with high prospects and expectations.

At this juncture, two striking points should be clarified so as to understand the importance of the TTIP for the EU and the US as well as for the world economy. The first point is the timing of the launch of the negotiations on the TTIP and the second is the role of the regulatory cooperation within the TTIP. Regarding the timing of the launch of the negotiations on the TTIP, the leaders and the policy makers both in the EU and the US were looking for something to boost their economies after the catastrophic global financial crises of 2008. The EU was frustrated by the monetary problems and limited financial freedom and such a launch would refresh the economic confidence on the EU economy. On the US side, the main motivation for launching the TTIP might be to eliminate EU concerns that the US had written her off in its pivot to Asia (Ikenson, 2013: 24). Regarding the second point about the role of the regulatory cooperation within the TTIP, the examination of the trade and investment flows between the EU and the US has a strategic importance.

During the examination of the trade flows between the EU and the US, it was impossible to access to the trade data by SITC Section from 1960 on. So as to present an analogous and convenient data, the 1999-2013 period is also analyzed. When the trade flows between the EU and the US during 1999-2013 are examined, the trade surplus of the EU on its trade with the US constitutes one of the important 
points. In 2013, the US was the third biggest import partner and the major export partner of the EU while the EU was the second major import and export partner of the US. Within the imports of the EU from the US by SITC Section during 19992013, the biggest share belongs to the Machinery and Transport Equipment while the Chemicals and Related Products, N.E.S. constitutes the second. The Miscellaneous Manufactured Articles which remains the third biggest share has a more or less stationary trend. Within the exports of the EU to the US at the same period, the Machinery and Transport Equipment is the leading Section. The Chemicals and Related Products, N.E.S., the Miscellaneous Manufactured Articles and the Manufactured Goods Classified Chiefly by Material are following the Machinery and Transport Equipment Section.

According to the trade flows data, there seems an intra-industry trade especially in the Machinery and Transport Equipment Section as well as in the Chemicals and Related Products, N.E.S. Section and Miscellaneous Manufactured Articles Section. According to the Ecorys (2009) leading study, the non-tariff barriers in these industries are relatively high. So as to enjoy the increasing economies of scale arising from the intra-industry trade, the parties should achieve the regulatory cooperation and abolish or at least decrease the existing non-tariff barriers in advance. Essentially, this economic rationale might be regarded as the fundamental reason of the significance of achieving the regulatory cooperation and negotiating on the non-tariff barriers within the TTIP.

On the other hand, before concluding on the FDI flows between the EU and the US, it should be reminded that it was unfortunately impossible to reach to the data before the 2000s. Thus, the data of 2001-2012 period is taken into examination in which the free movement of capital is more liberalized. Depending on the FDI flows during 2001-2012, the US has the biggest share within the extra EU-27 FDI inward as well as outward stocks. Though the US constitutes the major FDI partner of the EU both in the inward and outward stocks, the decreasing trend in its share is also remarkable. The reason of this decreasing trend could be either the nontariff and regulatory barriers or the attractiveness of investing in the emerging economies. The CEPR Report (2013) highlighted that there are non-tariff barriers on the free flow of FDI between the EU and the US and the highest impositions are on the aerospace industry, automobile industry, chemicals and cosmetics industry, textiles, clothing, footwear industry, paper and wood products industry and the transportation services.

Though it is hard to evaluate the TTIP properly before the end of its negotiation process, the positive outcomes of the elimination of the barriers on trade and investment are evident. The leading, independent CEPR Report (2013) refers to non-tariff barriers as the most efficient restriction on the free flow of transatlantic trade and investment. Furthermore, the Report estimates the macroeconomic 
effects of the liberalization of trade and investment between the EU and the US in terms of changes with regard to a projected 2027 global economy. According to the estimates of the CEPR Report, both the EU and the US will experience GDP growth but the increase in the GDP of the EU will be higher than the US. Although the parties will experience an improvement in bilateral exports, the remarkable increase will be on the total exports of the EU and the US in the comprehensive liberalization alternative. As a sum up, the latest transatlantic initiative referred to as the TTIP is at the early stages of negotiation and will be shaped depending on the interests of the negotiators. Admittedly, the most anticipated outcome of the TTIP is a permanent settlement in the long-lasting trade disputes and binding commitments to refrain from new ones. Such an outcome would lead to a freer world trade and thus would help in increasing the global welfare as a whole.

It should be stated that the TTIP is substantially different than the previous closer economic cooperation initiatives considering its probable outcomes. If the negotiations on the TTIP agreement can be successfully concluded, the EU and the US can decide and shape the global trade and investment rules together. In other words, they can act on behalf of the WTO in determining and imposing the rules of global economy. This new role based on the TTIP can hinder the legal and the moral status of the WTO and its members. Another probable outcome of the TTIP can be its impact on the other trade partners of the EU and the US. The parties, especially the EU, have a cobweb of preferential trade relations spread all over the world. Certainly, the TTIP would affect the countries which are part of this preferential trade cobweb differently because of trade creation or diversion or dynamic effects arise from Transatlantic market integration. These probable outcomes entail further research and examination on the effects of the TTIP and are out of the scope of this paper. To conclude, it should be admitted that the economic protectorate for the EU comes to its end and a new era of an equal economic footing has started together with the introduction of the TTIP, reflecting a new-age relationship. 


\section{References:}

Ahearn, R., J. (2011), US-EU Trade and Economic Relations: Key Policy Issues for the $112^{\text {th }}$ Congress, Congressional Research Service, Report for Congress, http://transatlantic.sais-jhu.edu/transatlantic-topics/Articles/economy/U.S.-

EU_Trade_and_Economic_Relations_CRS.pdf, Retrieved on: October 12, 2013.

Baskett, Y., (2010), 'Clash of the Titans: Boeing, Airbus and the WTO', Otago Management Graduate Review, Vol.8, pp. 1-12.

Benoit, E., (1961), Europe at Sixes and Sevens: The Common Market, the Free Trade Association and the United States, Colombia University Press, New York.

CEPR, (2013), Reducing Transatlantic Barriers to Trade and Investment: An Economic Assessment, http://rade.ec.europa.eu/doclib/docs/2013/march/tradoc_150737.pdf, Retrieved on: November 20, 2013.

Dür, A., (2008), 'Bargaining Power and Trade Liberalization: European External Trade Policies in the 1960s', European Journal of International Relations, Vol.14, No.4, pp. 645-669.

Echols, M. A., (1998), 'Food Safety Regulation in the European Union and the Unites States: Different Cultures, Different Laws', Colombia Journal of European Law, Vol.4, No.3, pp. 525-543.

Ecorys, (2009), Non-Tariff Measures in EU-US Trade and Investment-An Economic Analysis, Report Prepared by K. Berden, J.F. Francois, S. Tamminen, M. Thelle and P. Wymenga for the European Commission, Reference OJ 2007/S180-219493.

Eichengreen, B., (2007), The European Economy Since 1945, Princeton University Press, Princeton and Oxford, pp. 54-57.

Erixon, F., Bauer, M., (2010), A Transatlantic Zero Agreement, Estimating the Gains from Transatlantic Free Trade in Goods, ECIPE Occasional Paper, 4/2010, ECIPE, Brussels.

European Commission, (1998), Communication to the Council, the European Parliament and the Economic and Social Committee: The New Transatlantic Marketplace, (COM (98) 0125-C4-0271798).

European Commission, (2011), EU and US Boost Economic Partnership, http://rade.ec.europa.eu/doclib/docs/2011/november/tradoc_148386.pdf, Retrieved on: November 13, 2013.

European Commission, (2013a), EU-US High Level Working Group on Jobs and Growth,http://ec.europa.eu/enterprise/policies/international/cooperating-

governments/usa/jobs-growth/index_en.htm, Retrieved on: November 16, 2013.

European Commission, (2013b), EU and US Conclude First Round of TTIP Negotiations in Washington, http://europa.eu/rapid/press-release_IP-13-691_en.htm, Retrieved on: December 4, 2013. 
European Commission, (2013c), EU and US Conclude Second Round of TTIP Negotiations in Brussels, http://trade.ec.europa.eu/doclib/press/index.cfm?id=988, Retrieved on: December 6, 2013.

European Commission, (2013d), EU Chief Negotiator Says EU - US Trade Deal Not About Deregulation, as Third Round of Talks End in Washington, http://rade.ec.europa.eu/doclib/press/index.cfm?id=1007, Retrieved on: January 4, 2014.

European Commission, (2013e), Transatlantic Trade and Investment Partnership, The Regulatory Part, http://trade.ec.europa.eu/doclib/docs/2013/july/tradoc_151605.pdf, Retrieved on: February 15, 2014.

European Commission, (2014), EU, US Trade - Negotiators Explore Ways to Help SMEs Take Advantage of TTIP, as Fourth Round of Talks Ends in Brussels, http://trade.ec.europa.eu/doclib/press/index.cfm?id=1041, Retrieved on: April 29, 2014.

European Parliament and the Council, (2003a), 'Regulation (EC) No 1830/2003', Official Journal of the European Union, L 268/24, 18.10.2003.

European Parliament and the Council, (2003b), 'Regulation (EC) No 1829/2003', Official Journal of the European Union, L 268/1, 18.10.2003.

European Parliament, (2012), Win-Win Ending to the Hormone Beef Trade War, http://www.europarl.europa.eu/news/en/news-

$\mathrm{room} /$ content/20120314IPR40752/html/Win-win-ending-to-the-hormone-beef-tradewar, Retrieved on: November 22, 2013.

European Union External Action, (2007), Framework for Advancing Transatlantic Economic Integration between the European Union and the United States of America, http://www.eeas.europa.eu/us/docs/framework_trans_economic_integration07_en.pdf, Retrieved on: November 7, 2013.

Eurostat, (2014), 'International trade - Main tables', http://ec.europa.eu/eurostat/web/ international-trade/data/main-tables, Retrieved on: April 15, 2014.

Felbermayr, G., Mario, L., Lisandra, F., Erdal, Y., Sebastian, B., (2013), Dimensionen und Auswirkungen eines Freihandelsabkommens Zwischen der EU und der USA, Study Commissioned by German Federal Ministry of Economics and Technology, Munich.

Fontagné, L., Gourdon, J., Lean, S., (2013), Transatlantic Trade: Whither Partnership, Which Economic Consequences, Policy Brief, CEPII, Paris.

Freeland, R., M., (1972), The Truman Doctrine and the Origins of McCarthyism: Foreign Policy, Domestic Politics and Internal Security, 1946-1948, Alfred A. Knopf, New York.

Geneva Banana Agreement, (2009), WT/L/784, 15 December 2009.

German Presidency of the European Union, (2007), EU Presidency Statement on Transatlantic Relations to the Plenary of the European Parliament 25 April 
2007,http:/www.eu2007.de/en/News/Speeches_Interviews/April/0425AAGloserUSA.ht $\mathrm{ml}$, Retrieved on: November 7, 2013.

Gimbel, J., (1976), The Origins of the Marshall Plan, Stanford University Press, Stanford.

Hindley, B., (1999), 'New Institutions for Transatlantic Trade?', International Affairs, Vol.75,No.1, pp. 45-60.

Hudec, R., E., (1988), 'Legal Issues in US-EC Trade Policy: GATT Litigation 1960-1985', Issues in US-EC Trade Relations, Baldwin, R., E., Hamilton, C., B., Sapir, A. (eds), University of Chicago Press, Chicago, pp. 15-64.

IFO, (2013), Bunderländer, Branchen und Bildungsgruppen, Wirthschaftliche Folgen eines Transatlantischen Freihandelsabkommens (THIP) für Deutschland, Microökonomische Analyse, Co-authered by Felbermayr, G., Lehwald, S., Schoof, U., Ronge, M., Bertelsmann Foundation, Gütersloh.

Ikenson, D., (2013), 'Fresh Ideas for a Successful Transatlantic Trade and Investment Partnership', CESifo Forum, 4 (December).

Jackson, S., (1979), 'Prologue to the Marshall Plan: The Origins of the American Commitment for a European Recovery Plan', The Journal of American History, Vol.65, No.4, pp. 1043-1068.

Krause, L. B., (1968), European Economic Integration and the United States, Brookings Institution, Washington DC.

Kreinin, M. E., (1959), 'European Integration and American Trade', The American Economic Review, Vol.49, No.4, pp. 615-627.

Krugman, P. R., Obstfeld, M., Melitz, M. J., (2012), International Economics, Pearson, United States of America.

Kysar, D. A., (2004), 'Preferences for Processes: The Process/Product Distinction and the Regulation of Consumer Choice', Harvard Law Review, Vol.118, No. 2, pp. 525-642.

LaFeber, W., (1967), America, Russia and the Cold War 1945-1966, Wiley, New York.

Langhammer, R. J., Piazolo, D., Siebert, H. (2002), 'Assessing Proposals for a Transatlantic Free Trade Area', Aussenwirtschaft, June, pp. 161-185.

Lester, S., Barbee, I., (2013), 'The Challenge of Cooperation: Regulatory Trade Barriers in the Transatlantic Trade and Investment Partnership', Journal of International Economic Law, Vol.16, No.4, pp. 847-867.

Office of the United States Trade Representative, (2014), Readouts from TTIP Negotiating

Rounds, http://www.ustr.gov/trade-agreements/free-trade-agreements/transatlantictrade-and-investment-partnership/readouts/round5, Retrieved on: May25, 2014.

Osgood, R., E., (1953), Ideals and Self-Interest in America's Foreign Relations: The Great Transformation of the Twentieth Century, University of Chicago Press, Chicago. 
Pavcnik, N., (2002), 'Trade Disputes in the Commercial Aircraft Industry', The World Economy, Vol.25, No.5, pp. 733-751.

Piquet, H. S., (1958), 'First Effects of the Common Market: The Impact of Changing Tariffs on US Exports', The European Common Market: New Frontier for American Business, American Management Association, New York, pp. 124-159.

Pollark, M., A., (2003), The Political Economy of the Transatlantic Partnership, Robert Schuman Centre for Advanced Studies, Italy, pp. 5-9.

Price, H., B., (1955), The Marshall Plan and Its Meaning, Cornell University Press, Ithaca.

Read, R., (2005), 'The EU-US WTO Steel Dispute: The Political Economy of Protection and the Efficacy of the of the WTO Dispute Settlement Understanding', The WTO and the Regulation of International Trade, Perdikis, N., Read, R. (eds), Cheltenham, Edward Elgar Publ., pp. 135-175.

Salvatore, D., (2007), International Economics, Wiley, United States of America.

Schott, J., J., Oegg, B. (2001), 'Europe and the Americas: Toward a TAFTA-South?', The World Economy, Vol.24, No.6, 745-759.

Stimson, H., L., (1947), 'The Challenge to Americans', Foreign Affairs, 26, pp. 5-14.

Swinbank, A., (2005), 'The CAP as a Catalyst for Trade Dispute between the EU and the United States', The WTO and the Regulation of International Trade, Perdikis, N., Read, R. (eds), Cheltenham, Edward Elgar Publ., pp. 63-85.

The High Level Working Group on Jobs and Growth, (2012), 'Interim Report to Leaders from the Co-Chairs', http://trade.ec.europa.eu/doclib/docs/2012/june/tradoc_149557.pdf, Retrieved on: January 24, 2014.

The High Level Working Group on Jobs and Growth, (2013), Final Report, http://trade.ec.europa.eu/doclib/docs/2013/february/tradoc_150519.pdf, Retrieved on: March 14, 2014.

Transatlantic Economic Partnership: Action Plan, (1999), European Business Journal, Vol.1, No.1, 24-35.

Tyson, L., D., (1992), Who's Bashing Whom? Trade Dispute in High-Technology Industries, Institute for International Economics, Washington DC.

Urwin, D., W., (1991), The Community of Europe: A History of European Integration Since 1945, Longman, London and New York, pp. 15-16.

Walker, M., (1997), 'George Marshall: His Plan Helped Save Europe', Europe, 365, pp. 2225.

Welfens, P. J. J., Irawan, T., (2014), 'Transatlantic Trade and Investment Partnership: Sectoral and Macroeconomic Perspectives for Germany, the EU and the US', IZA Policy Paper No. 78, Forschungsinstitut zur Zukunft der Arbeit Institute for the Study of Labor, January 2014. 
WTO, (2000), 'US - Definitive Safeguard Measures on Imports of Wheat Gluten from the EC' Report of the Appellate Body, Geneva, WT/DS166/AB/R, 22 December 2000.

WTO, (2002), 'US - Section 211 Omnibus Appropriations Act of 1998', Report of the Appellate Body, Geneva, WT/DS176/AB/R, 2 January 2002.

WTO, (2003a), 'United States-Definitive Safeguard Measures on Imports of Certain Steel Products', Report of the Panel, Geneva: WTO/DS248/R.

WTO, (2003b), 'US - Continued Dumping and Subsidy Offset', WT/DS217/AB/R, Report of the Appellate Body, Geneva, 16 January 2003.

WTO, (2005a), 'European Communities - Protection of Trademarks and Geographical Indications for Agricultural Products and Foodstuffs', Report of the Panel, Geneva, WT/DS174/R, 15 March 2005.

WTO,(2005b), 'US - Countervailing Measures Concerning Certain Products from the EC', Report of the Panel, Geneva, WT/DS212/RW, 17 August 2005.

WTO, (2006a), 'European Communities - Measures Affecting the Approval and Marketing of Biotech Products', Report of the Panel, Geneva, WT/DS291/R, 29 September 2006.

WTO, (2006b), 'EC - Selected Customs Matters', Report of the Appellate Body, Geneva, WT/DS315/AB/R, 13 November 2006.

WTO, (2007), 'US - Laws, Regulations and Methodology for Calculating Dumping Margins (Zeroing)', Report of the Appellate Body, Geneva, WT/DS294/AB/R/Corr.1, 20 August 2007.

WTO, (2009), 'Geneva Agreement on Trade in Bananas', WT/L/784, 15 December 2009.

WTO, (2010), 'European Communities and Certain Member States - Measures Affecting Trade in Large Civil Aircraft', Report of the Panel, Geneva: WT/DS316/R, 30 June 2010.

WTO, (2011), 'European Communities and Certain Member States - Measures Affecting Trade in Large Civil Aircraft', Report of the Appellate Body, Geneva, WT/DS316/AB/R, 18 May 2011.

WTO, (2012a), Historic Signing Ends 20 Years of EU - Latin American Banana Disputes, http://www.wto.org/english/news_e/news12_e/disp_08nov12_e.htm, Retrieved on: March 2, 2014.

WTO, (2012b), European Communities - Measures Affecting Trade in Large Civil Aircraft,http://www.wto.org/english/tratop_e/dispu_e/cases_e/ds316_e.htm, Retrieved on: March 4, 2014. 